Sains Malaysiana 50(3)(2021): 879-887

http://dx.doi.org/10.17576/jsm-2021-5003-28

\title{
Association between Climatic Conditions, Population Density and COVID-19 in Indonesia
}

(Perkaitan antara Keadaan Iklim, Kepadatan Penduduk dan COVID-19 di Indonesia)

\author{
R. AzizaH*, Santi Martini, Lilis Sulistyorini, Mahmudah, Aditya Sukma PaWitra, Didik Budijanto, \\ Stefanny Surya Nagari, Cendana Fitrahanjani, Fairuz HaniYah Ramadhani \& Mohd. TALib Latif
}

ABSTRACT

The first emergence of Corona Virus Disease 2019 (COVID-19) confirmed cases found in Wuhan, China, has become a global crisis. At least 177 countries have been affected over 43,000,000 confirmed cases of corona positive and more than one million deaths until October 27th, 2020. Recent research has analyzed any possible factors causing the COVID-19 spreads were climate factors and population density. Indonesia was a tropical region known as the high-populated country in the World, with a 52.9\% area with a high mean air temperature and over 267.7 million populations. Our study aims to analyze the correlation between climate, population density, and COVID-19 in Indonesia. We used the K-means cluster method and Fisher's exact test to determine climatic conditions, population density, and COVID-19 clusters and study the correlation. Our research found that there is a correlation between climatic conditions and population density with COVID-19 (p: 0,034; p:0,004). Warmer climate conditions and densely populated regions contributed to the risen COVID-19 transmission in Indonesia. These are highlighted by the evidence of the top six provinces with highest COVID-19 cases are province classified in warmer climatic conditions (high air temperature, low rainfall, and humidity) and a fairly-dense to densely populated region.

Keywords: Climatic conditions; COVID-19; population density

\section{ABSTRAK}

Kemunculan pertama Penyakit Virus Corona 2019 (COVID-19) mengesahkan kes yang dijumpai di Wuhan, China, telah menjadi krisis global. Sekurang-kurangnya 177 negara telah dijangkiti dengan lebih 43,000,000 kes yang disahkan positif korona dan lebih daripada satu juta kematian sehingga 27 Oktober 2020. Penyelidikan terkini telah menganalisis faktor kemungkinan yang menyebabkan penyebaran COVID-19 iaitu faktor iklim dan kepadatan penduduk. Indonesia adalah wilayah tropik yang terkenal sebagai negara berpopulasi tinggi di dunia dengan luas 52.9\% dan min suhu udara tinggi dengan lebih 267.7 juta penduduk. Kajian kami bertujuan untuk menganalisis hubungan antara iklim, kepadatan penduduk dan COVID-19 di Indonesia. Kami menggunakan kaedah kluster K-means dan ujian tepat Fisher untuk menentukan keadaan iklim, kepadatan penduduk dan kelompok COVID-19 dan mengkaji korelasi tersebut. Penyelidikan kami mendapati bahawa terdapat hubungan antara keadaan iklim dan kepadatan penduduk dengan COVID-19 (p: 0,034; p: 0,004). Keadaan iklim yang lebih panas dan kawasan berpenduduk padat menyumbang kepada peningkatan jangkitan COVID-19 di Indonesia. Ini disoroti dengan bukti enam wilayah teratas dengan kes COVID-19 tertinggi adalah wilayah yang dikelaskan dalam keadaan iklim yang lebih panas (suhu udara tinggi, hujan yang rendah dan kelembapan) dan wilayah yang hampir padat hingga berpenduduk padat.

Kata kunci: COVID-19; keadaan iklim; kepadatan penduduk

\section{INTRODUCTION}

Starting at the end of 2019, a new respiratory disease, which was later named COVID-19, were found in Wuhan, China. This disease is caused by a novel coronavirus (SARS$\mathrm{CoV}-2$ ). The virus has spread throughout China within two months, which then develops into various countries. The World Health Organization (WHO) has declared the epidemic of public health emergencies since January 30th, 2020 (WHO 2020a). This pandemic has caused panic around the World since the beginning of 2020. There were 177 countries with over 43,000,000 confirmed cases and more than 1,000,000 deaths until October 27th, 2020 (WHO 2020b).

Elderly and people with congenital diseases are considered to be a high-risk group for COVID-19. The disease is spread through direct and indirect contact (Dangi 2020). Through direct contacts, droplets can spread up to 1-2 $\mathrm{m}$ from the contact source. Many studies predict that the virus can spread through the air (Wang \& Du 2020), looking at the rapid spread of COVID-19. Some research was done 
to prove the spread of the SARS-CoV-2 virus in addition to through droplets. In October, The Center for Disease Control and Prevention (CDC) announced that the virus could spread through the air (CDC 2020). The CDC's statement further confirmed that the spread of the virus is very frightening because the potential spread of the virus is more comfortable and faster when it is through the air. The theory states that crowds can be the most vulnerable source for COVID-19 spread.

To date, the increase in daily COVID-19 cases in Indonesia is still an alarming number. Apart from manageable factors that can control the COVID-19 confirmed cases increase, there are some uncontrollable factors that we cannot handle, such as climate and population density and many other pre-existing conditions which increase the risk of death from COVID-19. Scientists in the United States government estimate that COVID-19 could kill 10 out of 1000 Americans. Crowd increases the potential for human contact and is a primary source of human-to-human transmissions. COVID-19 growth significantly in denser areas (Therese 2020). Another study on climate and COVID-19 in Brazil, with an annual average temperature, ranges from $16.8{ }^{\circ} \mathrm{C}$ to $27.4{ }^{\circ} \mathrm{C}$, found a negative linear association between temperature and the number of COVID-19 cases. They also found that the increase of $1{ }^{\circ} \mathrm{C}$ is associated with a decrease of $-4.8951 \%(\mathrm{t}=-2.29, \mathrm{p}=0.0226)$ in the cumulative daily number of confirmed cases of COVID-19 (Prata et al. 2020). Research on population density, wind speed and COVID 19 has also been conducted in Turkey by Coskun et al. (2020). The results showed that population density and wind, accounting for $94 \%$ of the virus spread variance, had a significant impact on the spread of the virus or the number of cases. Coskun et al. (2020) stated that the virus is spreading more in windy weather, indicating that the air threatens humans with wind speeds. A cluster and regression model was carried out on the group of cities with the highest COVID-19 cases, and the highest population density in Algeria shows a strong correlation between population density and the number of COVID-19 infections.
The results showed that population density positively affected the spread of COVID-19 (Kadi et al. 2020).

Indonesia is a highly-populated country; Indonesia's population deploys across 34 provinces, so does the climatic conditions. Although it is a tropical area, climatic conditions in various provinces in Indonesia are diverse. Some regions may have a lower air temperature than others. Given these diverse conditions in Indonesia, it is necessary to study the climate conditions and population density to see whether these two factors are related to the enormous COVID-19 event in Indonesia. This study analyzes the correlation between climatic conditions (temperature, rainfall, and humidity), population density, and COVID-19 in 34 provinces in Indonesia.

\section{MATERIALS AND METHODS}

This research was conducted in Indonesia using climatic conditions, population density, and COVID-19 data from secondary resources. Climatic conditions data are collected from Indonesia's Environmental Statistics 2019 report (BPS 2019). Due to the limitation of data in Indonesia, we used the 2019 climate conditions in this study. Population density data is collected from the Indonesia Statistics 2020 report (BPS 2019). COVID-19 data used in this study is a cumulative data of total, recovered, and death cases from early March until July 22, 2020. The data collected from COVID-19 Daily Media Report, Indonesian Health Ministry. There were 34 Province in Indonesia, which illustrated in Figure 1.

This study used computer-based data processing with a statistical approach. There were two analyses conducted in this study: K-means cluster and Fisher's exact test. $\mathrm{K}$-means cluster was used to determine the clusters of climatic conditions, population density, and COVID-19. Fisher's exact test is used to determine the correlation between the climatic condition and COVID-19 and the correlation between population density and COVID-19.

\section{RESULTS AND DISCUSSION}

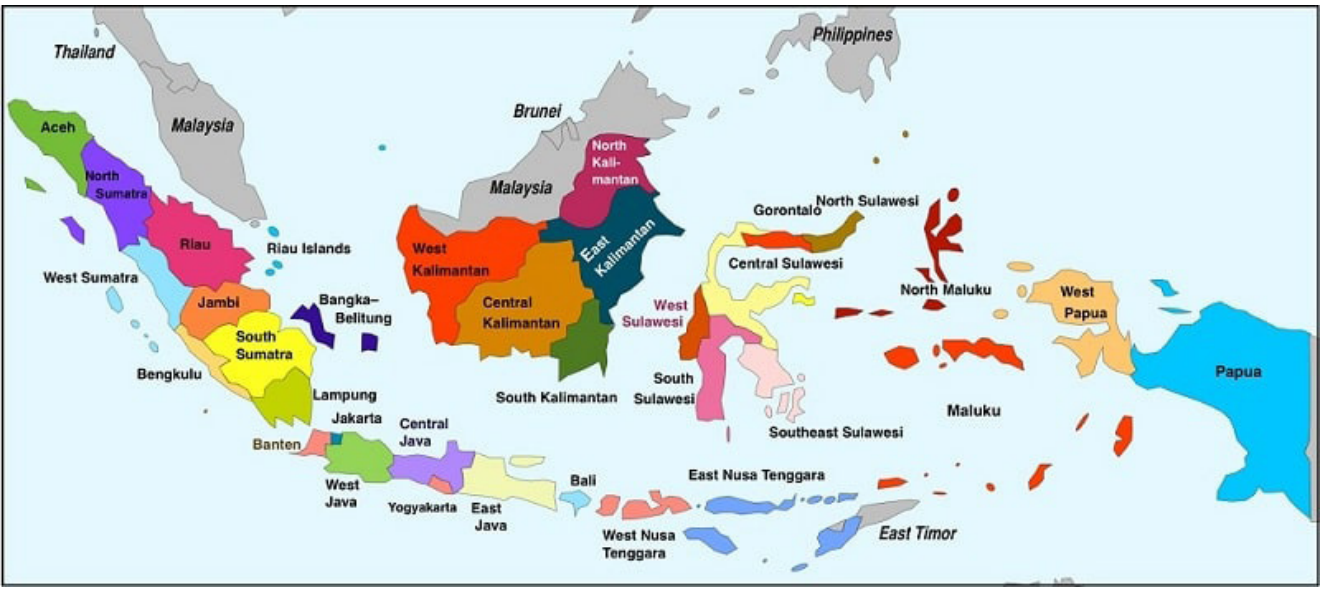

FIGURE 1. Indonesia Map

Source: https://peta-hd.com/peta-34-provinsi-di-indonesia/ 
COVID-19 CLUSTER SPREADS IN INDONESIA

K-means cluster is used to determine the COVID-19 clusters. There are three indicators used to determine the
COVID-19 clusters; total, recovered, and death cases. Table 1 shows three COVID-19 clusters; low, medium, and high.

TABLE 1. COVID-19 cluster cases positive, recovered, and

deaths

\begin{tabular}{|c|c|c|c|c|c|c|c|c|c|}
\hline \multirow{3}{*}{ Measure } & \multicolumn{9}{|c|}{ COVID-19 Clusters } \\
\hline & \multicolumn{3}{|c|}{ Low } & \multicolumn{3}{|c|}{ Medium } & \multicolumn{3}{|c|}{ High } \\
\hline & Total cases & Recovered & Deaths & Total cases & Recovered & Deaths & Total cases & Recovered & Deaths \\
\hline Min & 136 & 75 & 1 & 3149 & 1472 & 144 & 17621 & 10460 & 751 \\
\hline Max & 8407 & 5034 & 287 & 7726 & 3720 & 444 & 19093 & 11139 & 1496 \\
\hline Mean \pm SD & $\begin{array}{c}1185,54 \pm \\
1677,51\end{array}$ & $\begin{array}{c}674,61 \pm \\
981,39\end{array}$ & $\begin{array}{c}41,39 \pm \\
62,29\end{array}$ & $\begin{array}{c}5458 \pm \\
1880,95\end{array}$ & $\begin{array}{c}2441,75 \pm \\
941,11\end{array}$ & $\begin{array}{c}263,25 \pm \\
129,77\end{array}$ & $\begin{array}{l}18357 \pm \\
1040,86\end{array}$ & $\begin{array}{c}10799,5 \pm \\
480,12\end{array}$ & $\begin{array}{c}1123,5 \pm \\
526,79\end{array}$ \\
\hline
\end{tabular}

From Table 1, low clusters are cluster with lower total COVID-19 cases than the medium and high cluster. The recovery rate means recovered cases per mean total cases in each cluster in the low cluster are $56.9 \%$. It is higher than the medium cluster with a $44.73 \%$ recovery rate and lower than the high cluster is $58.83 \%$. The case fatality rate means death cases per mean total cases in each cluster; in the low cluster, they are lower with a $3.49 \%$ than the medium cluster $4.82 \%$ and high cluster $6.12 \%$.

From the cluster analysis, 28 provinces classified in low clusters are Aceh; Bali; Banten; Bangka Belitung; Bengkulu; DI Yogyakarta; Jambi; West Kalimantan; East Kalimantan; Central Kalimantan; North Kalimantan;
Riau Islands; West Nusa Tenggara; South Sumatra; West Sumatra; North Sulawesi; North Sumatra; Southeast Sulawesi; Central Sulawesi; Lampung; Riau; North Maluku; Maluku; West Papua; Papua; West Sulawesi; East Nusa Tenggara; and Gorontalo. Four provinces classified in medium clusters are West Java Province; Central Java; Kalimantan Selatan; and South Sumatra. Two clusters are classified in high clusters are East Java and Jakarta.

Figure 2 shows the six provinces in Indonesia with the highest number of total cases: East Java 19,093; Jakarta 17,621; South Sulawesi 8,407; Central Java 7,726; West Java 5,741; and South Kalimantan 5,216.

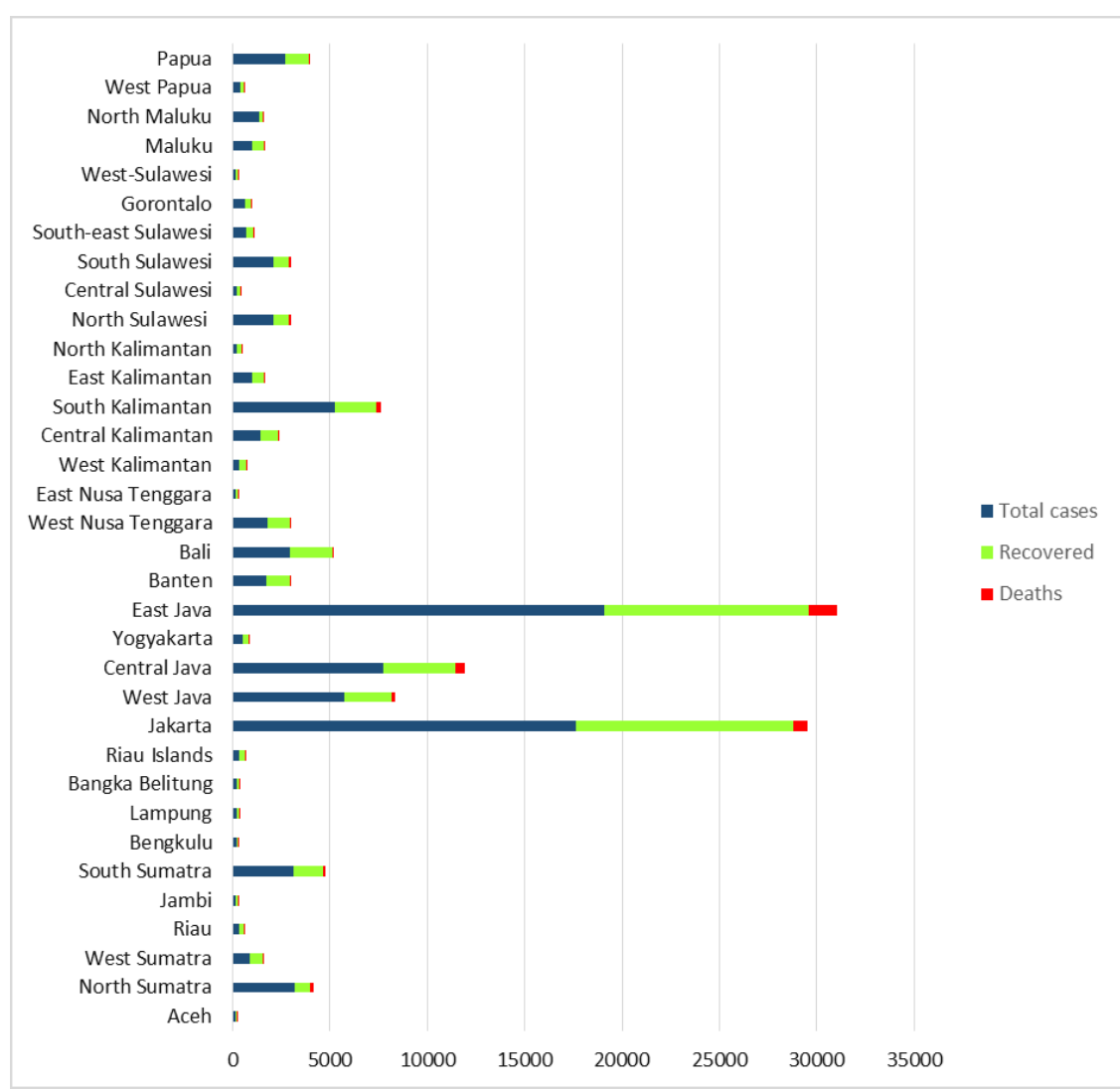

FIGURE 2. Number of COVID-19 cases spread across 34 provinces in Indonesia 
CORRELATION BETWEEN CLIMATIC CONDITIONS

(TEMPERATURE, HUMIDITY, AND RAINFALL) AND COVID-19 IN INDONESIA

Climatic Conditions (Temperature, Humidity, and Rainfall) In Indonesia

There are three climate indicators used to determine the Climatic Conditions cluster; air temperature, rainfall, and humidity. The three indicators used different units, so a value standardization is performed. There are two Climatic Conditions clusters; Climatic Conditions I and Climatic Conditions II (Table 2).

TABLE 2. Climate clusters (temperature, rainfall, and humidity) in climatic conditions i and climatic conditions ii of 34 provinces in Indonesia

\begin{tabular}{|c|c|c|c|c|c|c|}
\hline \multirow{3}{*}{ Measure } & \multicolumn{6}{|c|}{ Climate clusters } \\
\hline & \multicolumn{3}{|c|}{ Climatic conditions I } & \multicolumn{3}{|c|}{ Climatic conditions II } \\
\hline & $\begin{array}{c}\text { Temperatures } \\
\left({ }^{\circ} \mathrm{C}\right)\end{array}$ & $\begin{array}{c}\text { Rainfall } \\
\text { (mm/year) }\end{array}$ & $\begin{array}{c}\text { Humidity } \\
(\%)\end{array}$ & $\begin{array}{c}\text { Temperatures } \\
\left({ }^{\circ} \mathrm{C}\right)\end{array}$ & $\begin{array}{c}\text { Rainfall } \\
\text { (mm/year) }\end{array}$ & Humidity $(\%)$ \\
\hline Min & 26,7 & 1585 & 80 & 25,9 & 490 & 67 \\
\hline Max & 28,3 & 3823 & 87 & 29,5 & 3048 & 82 \\
\hline Mean \pm SD & $27,3 \pm 0,44$ & $2693,5 \pm 597,88$ & $83,19 \pm 2,07$ & $28,22 \pm 0,91$ & $1840,5 \pm 578,81$ & $76,72 \pm 3,94$ \\
\hline
\end{tabular}

The mean air temperature in Climatic Conditions I is lower than Climatic Conditions II, while the mean rainfall and humidity in Climatic Conditions I are higher than the Climatic Conditions II. These show that Climatic Conditions I is a colder area than Climatic Conditions II. From the cluster analysis, 16 provinces within Climatic conditions I are Aceh; West Sumatra; Riau; Jambi; Bangka Belitung; Riau Islands; West Kalimantan; Central Kalimantan; North Kalimantan; North Sulawesi; South Sulawesi; Southeast Sulawesi; Maluku; North Maluku;
West Papua; Papua; and 18 provinces within Climatic conditions II are North Sumatra; South Sumatra; Bengkulu; Lampung; Jakarta; West Java; Central Java; Yogyakarta; East Java; Banten; Bali; West Nusa Tenggara; East Nusa Tenggara; South Kalimantan; East Kalimantan; Central Sulawesi; Gorontalo; West Sulawesi. This finding shows that $52.9 \%$ of Indonesia's area indicates having a high mean air temperature, low rainfall and humidity, included in Climatic conditions II (Table 3).

TABLE 3. The difference of cluster COVID-19 based on climate climatic conditions

\begin{tabular}{|c|c|c|c|c|c|c|c|c|c|c|}
\hline \multirow{3}{*}{ Climatic conditions } & \multicolumn{6}{|c|}{ Cluster COVID-19 } & \multirow{2}{*}{\multicolumn{2}{|c|}{ Total }} & \multirow{3}{*}{$\mathrm{P}_{\text {value }}$} & \multirow{3}{*}{$\begin{array}{l}\text { Correlation } \\
\text { coefficient }\end{array}$} \\
\hline & \multicolumn{2}{|c|}{ Low } & \multicolumn{2}{|c|}{ Medium } & \multicolumn{2}{|c|}{ High } & & & & \\
\hline & $\mathrm{n}$ & $\%$ & $\mathrm{n}$ & $\%$ & $\mathrm{n}$ & $\%$ & $\mathrm{n}$ & $\%$ & & \\
\hline Climatic conditions I & 16 & 100 & 0 & 0 & 0 & 0 & 16 & 100 & & \\
\hline Climatic conditions II & 12 & 66,7 & 4 & 22,2 & 2 & 11,1 & 18 & 100 & 0,034 & 0,400 \\
\hline Total & 28 & 82,4 & 4 & 11,8 & 2 & 5,9 & 34 & 100 & & \\
\hline
\end{tabular}

Our study found a correlation between Climatic Conditions and COVID-19 clusters $\mathrm{p}=0.034$ with a positive correlation coefficient of $40 \%$, indicates a strong correlation between climatic conditions and COVID-19. It shows a linear correlation, that higher climate conditions led to higher COVID-19 cases. All provinces in Climatic 
Conditions I have low COVID-19 cases. We predict that the coronavirus can live under high temperatures. Indonesia's mean air temperature ranges from 26.7 $29.5^{\circ} \mathrm{C}$ and COVID-19 spread in Indonesia is also high. The condition is not according to the previous studies state that coronavirus can survive with lower air temperatures 5-11 ${ }^{\circ} \mathrm{C}$ (Sajadi et al. 2020). However, Indonesia's humidity level is relatively high, ranging from $67-87 \%$ to the range of humidity, which is considered following the coronavirus environment (44-88\%) (Sajadi et al. 2020). The humidity level in Indonesia is suitable for the survival of the coronavirus. We predict humidity is an essential climate factor in the survival of the coronavirus.

A study conducted in Brazil showed that warm temperature (above $25^{\circ} \mathrm{C}$ ) were not associated with the declined of the COVID-19 cases (Prata et al. 2020). Pan et al. (2020) suggest that warmer weather unlikely to reduce the COVID-19 transmissions. Although a surge in COVID-19 cases in the hot and humid region is not as rapid as in the cold and dry region, COVID-19 cases in the hot and humid region keep increasing consistently. Warm weather alone may not be able to stop the COVID-19 transmissions and several other factors other than meteorological factors should be taken into account (Bukhari et al. 2020). The spread of COVID-19 appears to be lower in warm and wet climates, but the certainty of the resulting evidence is rated low. Temperature and humidity alone do not explain most of the variability of the COVID-19 outbreak. The spread of COVID-19 may be influenced by other factors such as public isolation policy, herd immunity, migration patterns, population density, and cultural aspects (Macenas et al. 2020).
CORRELATION BETWEEN POPULATION DENSITY (POPULATION AND AREA OF PROVINCE) AND COVID-19 IN INDONESIA

Population Density (Population and Area of Province) In Indonesia

Various studies on population density correlation and COVID-19 spread are conducted in the world. Some studies found that population density correlates with COVID-19 distribution rates, while others found the opposite. According to research conducted in China, population density is not related to COVID-19 events. However, Sun et al. (2020) stated that territorial restriction is a useful measure in reducing the chance of infection in the community. Territorial restrictions, commonly referred to as regional quarantine, are traditional solutions used in antiquity to control the spread of infectious diseases (Wilder-Smith \& Freedman 2020). This step is useful to limit communities' interaction within the region so that the virus does not increasingly spread mainly in densely populated areas.

High-density regions can cause the spread of the SARS-Cov-2 virus faster than lower density regions, based on research conducted in Japan (Sajadi et al. 2020). High-density levels increase the likelihood of physical contact with others due to increasingly limited wiggle room (Ramadhani 2020). Besides, population in densely populated areas will have less chance of treating properly if the health service in the region is inadequate inpatient surges. Population density is related to the number of COVID-19 cases, the case fatality rate from COVID-19, and the willingness of health services in the region (Amoo et al. 2020) (Table 4).

TABLE 4. Population density of 34 provinces in Indonesia

\begin{tabular}{lccc}
\hline \multirow{2}{*}{ Measure } & \multicolumn{3}{c}{ Population density } \\
\cline { 2 - 4 } & Low & Medium & High \\
\hline Min & 9 & 750 & 15900 \\
Max & 273 & 1394 & 15900 \\
Mean \pm SD & $101,15 \pm 77,79$ & $1099,67 \pm 266,77$ & $15900 \pm .^{*}$ \\
\hline
\end{tabular}

${ }^{1}$ Standard Deviation unable to calculate, as there is only 1 Province

We divided population density into three categories; low, medium, and high. Population density is the amount that represents how dense the population in one particular area. Population density is calculated by dividing the population by the area. There is a large discrepancy in high population density compared to the low and medium population. 
There are 27 low density provinces, Aceh; North Sumatra; West Sumatra; Riau; Jambi; South Sumatra; Bengkulu; Lampung; Bangka Belitung; Riau Islands; West Nusa Tenggara; East Nusa Tenggara; West Kalimantan; Central Kalimantan; South Kalimantan; East Kalimantan; North Kalimantan; North Sulawesi; Central Sulawesi;
South Sulawesi; North Sulawesi; Gorontalo; West Sulawesi; Maluku; North Maluku; West Papua; and Papua. The six medium density provinces are West Java; Central Java; Yogyakarta; East Java; Banten; Bali. The highdensity province is Jakarta. The province in Java Island has a medium to high population density (Figure 3 ).

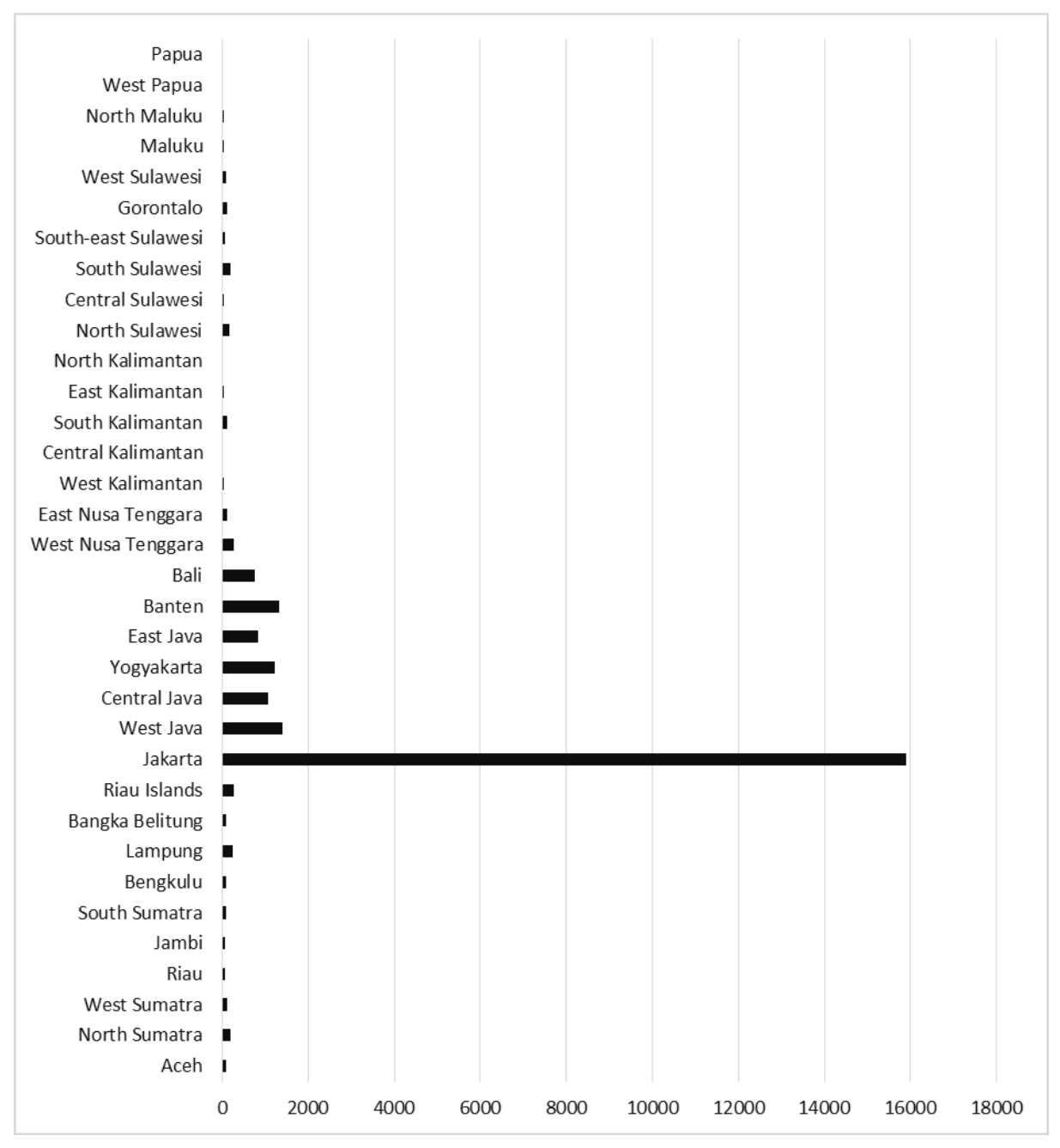

FIGURE 3. Population density of 34 provinces in Indonesia

Jakarta province has a high population of 15,900 people $/ \mathrm{km}^{2}$ with population is $10,557,800$ and 664.01 $\mathrm{km}^{2}$. Jakarta is one of the metropolitan areas with a dense population. In addition to having a dense population, Jakarta is one of the areas with a high positive case. Most metropolitan areas in different countries have dense populations. New York is one of the states of the United States with high population density and positive cases. In research conducted in the United States, New York accounted for $37 \%$ of positive cases in the United States. In addition to New York, other metropolitan areas such as Chicago, Washington, and Los Angles are also among the top ten densely populated metropolitan areas contributing to positive cases in the United States (Zhang \& Schwartz 2020) (Table 5). 
TABLE 5. The difference of Cluster COVID-19 Based on Population Density

\begin{tabular}{|c|c|c|c|c|c|c|c|c|c|c|}
\hline \multirow{3}{*}{ Population density } & \multicolumn{6}{|c|}{ Cluster COVID-19 } & \multirow{2}{*}{\multicolumn{2}{|c|}{ Total }} & \multirow{3}{*}{$\mathrm{P}_{\text {value }}$} & \multirow{3}{*}{$\begin{array}{l}\text { Correlation } \\
\text { coefficient }\end{array}$} \\
\hline & \multicolumn{2}{|c|}{ Low } & \multicolumn{2}{|c|}{ Medium } & \multicolumn{2}{|c|}{ High } & & & & \\
\hline & $\mathrm{n}$ & $\%$ & $\mathrm{n}$ & $\%$ & $\mathrm{n}$ & $\%$ & $\mathrm{n}$ & $\%$ & & \\
\hline Low & 25 & 92,6 & 2 & 0 & 0 & 0 & 27 & 100 & & \\
\hline Medium & 3 & 50 & 2 & 33,3 & 1 & 16,7 & 6 & 100 & & \\
\hline High & 0 & 0 & 0 & 0 & 1 & 100 & 1 & 100 & 0,004 & 0,633 \\
\hline Total & 28 & 82,4 & 4 & 11,8 & 2 & 5,9 & 34 & 100 & & \\
\hline
\end{tabular}

Our study found a correlation between population density and COVID- 19 with $\mathrm{p}=0.004$ and a positive correlation coefficient of $63.3 \%$. Based on cross-tabulation results, $92.6 \%$ of low-density provinces have low COVID-19 cases. As well as 100\% high-density have high COVID-19. This research is in line with research (Sarmadi et al. 2020) that population density in the United States affects deaths from COVID-19 in the United States. The greater the population density, the greater the mortality rate in the United States. Similar research was conducted in India, which ranks in the top ten of the world's top population as Indonesia. The research shows an association between population density and COVID-19 spread (Bhadra et al. 2020). This result is similar to this study and the United States study, which shows that population density has a role in the spread of COVID- 19 .

\section{SIX PROVINCES WITH THE HIGHEST COVID-19 CASES, CLIMATE CONDITIONS AND POPULATION DENSITY}

The Top Six Provinces with the Highest Cases, Climatic Conditions and Population Density

Our study found that the six provinces with the highest COVID-19 cases were in Climatic conditions II (high mean air temperature with low rainfall and humidity) (Table 6). The findings are in stark contrast, as research analyzing the effects of climate and weather on COVID-19 cases found that countries with high mean air temperatures and low humidity have the effect of lowering the number of deaths caused by COVID-19. A study found that tropical regions with high mean temperature and high relative humidity, i.e., India, Pakistan, Saudi Arabia, Malaysia,
Thailand, and Australia, have low death cases and high recovery rates (Pavani \& Sunalini 2020). Muhammad Mazhar et al. (2020) also discovered that tropical regions, i.e. Malaysia, Thailand, and Indonesia, are less affected by the coronavirus. However, Muhammad Mazhar et al. (2020) study the regional climatic condition's effect by June 2020. Some researchers also conducted a study in the subtropical climate, i.e. China. They also found that higher average air temperatures will lower the risk of COVID-19 (Ma et al. 2020; Wang et al. 2020). However, Indonesia's high mean temperature did not follow the same conditions related to COVID-19 in other regions. Coronavirus will still last inside the human body and infect other humans during the incubation period. The more frequent human activities outside the house, the more the virus will likely spread and infect other humans.

Based on our results, the top 6 provinces with the highest COVID-19 cases are located in a fairly dense and dense region. As a high-density region, Jakarta is the region with the second-highest COVID-19 cases, while East Java is in the first position is a fairly dense region. The rest following a sequence order are West Java, Central Java, South Kalimantan, and South Sumatra. This region is fairly dense. Our result found a similar study conducted by Jawad (2020), which states that the results of an analysis conducted in countries vulnerable to COVID-19 spread show that population density affects the peak period of COVID-19 spread. However, population density is not an essential factor in the spread of COVID-19 under strict lockdown policies. China's lockdown policy could effectively limit the speed at which COVID-19 spreads (Sun 2020). 
TABLE 6. Climatic conditions and population density in six provinces with the highest COVID-19 cases

\begin{tabular}{|c|c|c|c|c|}
\hline \multirow{2}{*}{ No. } & \multirow[b]{2}{*}{ Province } & \multicolumn{3}{|c|}{ Cluster } \\
\hline & & Covid 19 & Climatic conditions & Population density \\
\hline 1. & East Java & High Cases & II & Medium \\
\hline 2. & Jakarta & High Cases & II & High \\
\hline 3. & West Java & Medium Cases & II & Medium \\
\hline 4. & Central Java & Medium Cases & II & Medium \\
\hline 5. & South Kalimantan & Medium Cases & II & Medium \\
\hline 6. & South Sumatra & Medium Cases & II & Medium \\
\hline
\end{tabular}

\section{CONCLUSION}

Indonesia region is identified in high air temperature with $26.7-29.5^{\circ} \mathrm{C}$ and high humidity $(67-87 \%)$, due to its tropical climate. However, the majority of the province in Indonesia are classified in Climatic Conditions II in $52,9 \%$. Climatic conditions II is a Climatic condition with higher mean air temperatures, lower rainfall and humidity than the rest. Indonesia is also known as a highly-dense country. Jakarta is the most populated region in Indonesia (population density: 15,900). Our results found a correlation between the climatic conditions and the COVID-19 cluster (p:0,034), and there is a correlation between population density and COVID-19 clusters (p:0,004). Population density is more related to the high number of COVID-19 cases in Indonesia, which has a positive correlation of $63.3 \%$. The top six provinces that have the highest COVID-19 cases in Indonesia are classified in Climatic Conditions II and a fairly-dense to densely populated region. There need to be adaptation and mitigation measures in COVID-19 control related to climate conditions in Climatic conditions II and high population density so that policies in their respective provinces in crowd control, social distancing, and efforts to reduce COVID-19 cases through increased community-based awareness.

\section{ACKNOWLEDGEMENTS}

We would like to thank the Department of Environmental Health and Environmental Health Master Program, Faculty of Public Health, Universitas Airlangga which has facilitated the activities of writing scientific articles in the framework of international journal publication. We would also thank Prof. Mohd. Talib Latif, Universiti Kebangsaan Malaysia who guided and corrected this research until this article was compiled.

\section{REFERENCES}

Amoo, E.O., Adekeye, O., Olawole-Isaac, A., Fasina, F., Adekola, P.O., Samuel, G.W., Akanbi, M.A., Oladosun, M. \& Azuh, D.E. 2020. Nigeria and Italy divergences in coronavirus experience: Impact of population density. Scientific World Journal 2020: 8923036. DOI: 10.1155/2020/8923036.

Bhadra, A., Mukherjee, A. \& Sarkar, K. 2020. Impact of population density on Covid-19 infected and mortality rate in India. Modeling Earth Systems and Environment 7: 623-629.

BPS. 2020. Statistics Indonesia Statistical Year Book of Indonesia 2020. Accessed by https://drive.google.com/ file/d/18EfhKxnIARMh0h_4qqWsEszYsk_X0W8G/view.

BPS. 2019. Population by Age and Gender Group 2019. Indonesian Central Bureau of Statistics. https://www.bps. go.id/indikator/indikator/view_data_pub/0000/api_pub/58/ da $03 / 1$.

BPS. 2019. Indonesia Environmental Statistics 2019. https://www.bps.go.id/publication/2019/12/13/ e11bfc8ff8392e5e13a8cff3/statistik-lingkungan-hidupindonesia-2019.html.

Bukhari, Q., Massaro, J.M., D’Agostino Sr., R.B. \& Sheraz Khan. 2020. Effects of weather on coronavirus pandemic. International Journal of Environmental Research and Public Health 17(15): 5399. https://doi:10.3390/ ijerph17155399.

CDC. SARS-CoV-2 \& Potential Airborne Transmission [Internet]. 2020. Center for Disaese Control and Prevention. https://www.cdc.gov/coronavirus/2019-ncov/more/scientificbrief-sars-cov-2.html.

Coşkun, H., Yıldırım, N. \& Gündüz, S. 2020. The spread of COVID-19 virus through population density and wind in Turkey cities. Science of The Total Environment 751(10): 141663.

Dangi, R.R. \& George, M.A. 2020. Review on theories and models of disease causation for COVID-19. Journal SSRN Electron $2020 \mathrm{https}: / /$ doi.org/10.2139/ssrn.3584080. 
Jawad, A.J. 2020. Effectiveness of population density as natural social distancing in COVID19 spreading. Ethics Medicine and Public Health 15(C): 100556.

Kadi, N. \& Khelfaoui, M. 2020. Population density, a factor in the spread of COVID-19 in Algeria: Statistic study. Bulletin of the National Research Centre 44: 138. https://doi.org/10.1186/ s42269-020-00393-X.

Ma, Y., Zhao, Y., Liu, J., He, X., Wang, B., Fu, S., Yan, J., Niu, J., Zhou, J. \& Luo, B. 2020. Effects of temperature variation and humidity on the death of COVID-19 in Wuhan, China. Science of The Total Environment 724: 138226.

Mecenas, P., da Rosa Moreira Bastos, R.T., Rosário Vallinoto, A.C. \& Normando, D. 2020. Effects of temperature and humidity on the spread of COVID-19: A systematic review. PLOS ONE 15(9): e0238339.

Ministry of Health of Indonesia. 2020. Daily Media Report Covid-19 dated July 22, 2020 at 12.00 WIB.

Ministry of Health of Indonesia. 2020. COVID-19 Transmission Prevention Guide. https://promkes.kemkes.go.id/panduanpencegahan-penularan-covid-19-untuk-masyarakat.

Muhammad Mazhar Iqbal, Irfan Abid, Saddam Hussain, Naeem Shahzad, Muhammad Sohail Waqas \& Muhammad Jawed Iqbal. 2020. The effects of regional climatic condition on the spread of COVID-19 at global scale. Sci. Total Environ. 15(739): 140101.

National Health Commission of People's Republic of China. 2020. Pneumonia Diagnosis and Treatment of 2019-nCoV Infection from Chinese NHC and CDC 2020.

Pan, J., Yao, Y., Liu, Z., Meng, X., John, S. Ji., Qiu, Y., Wang, W., Zhang, L., Wang, W. \& Kan, H. 2020. Warmer weather unlikely to reduce the COVID-19 transmission: An ecological study in 202 locations in 8 countries. Science of The Total Environment 753: 142272.

Pavani, A. \& Sunalini, K.K. 2020. Effects of temperature and relative humidity on Covid-19. Journal of Critical Reviews 7(9): 3177-3182.

Prata, D.N., Rodrigues, W. \& Bermejo, P.H. 2020. Temperature significantly changes COVID-19 transmission in (sub) tropical cities of Brazil. Science of The Total Environment 729: 138862.

Ramadhani, F.H. 2020. Literature review: Healthy home as the new normal for Covid-19 prevention. Jurnal Kesehatan Lingkungan doi: 10.20473/jkl.v12i1si.2020.1-10.

Sajadi, M.M., Habibzadeh, P., Vintzileos, A., Shokouhi, S., Miralles-Wilhelm, F. \& Amoroso, A. 2020. Temperature, humidity, and latitude analysis to estimate potential spread and seasonality of Coronavirus Disease 2019 (COVID-19). JAMA Network Open 3(6): e2011834.

Sarmadi, M., Moghanddam, V.K., Dickerson, A.S. \& Martelletti, L. 2020. Association of COVID-19 distribution with air quality, sociodemographic factors, and comorbidities: An ecological study of US states. Air Quality, Atmosphere \& Health https://doi.org/10.1007/s11869-020-00949-w.
Sun, Z., Zhang, H., Yang, Y., Wan, H. \& Wang, Y. 2020. Impacts of geographic factors and population density on the COVID-19 spreading under the lockdown policies of China. Science of The Total Environment 746(666): 141347.

Therese, K.L.S., White, L.F. \& Nichols, B. 2020. Population density and basic reproductive number of COVID-19 across United States counties. National Library of Medicine https:// doi.org/10.1101/2020.06.12.20130021.

Wang, H., Chen, C. \& Lin, Q. 2020. Short-term effects of ambient temperature and relative humidity on the risk of COVID-19 and SARS in Guangzhou, China: A time-series analysis. Research Square doi: 10.21203/rs.3.rs-50445/v1.

Wang, J. \& Du, G. 2020. COVID-19 may transmit through aerosol Irish Journal of Medical Science 89: 1143-1144.

WHO. 2020a. Infection prevention and control guidance for long-term care facilities in the context of COVID-19. Interim Guidance of World Health Organization. https://apps.who. int/iris/handle/10665/331508.

WHO. 2020b. WHO Corona Disease (COVID-19) Dashboard. https://covid19.who.int/.

Wilder-Smith, A. \& Freedman, D.O. 2020. Isolation, quarantine, social distancing and community containment: Pivotal role for old-style public health measures in the novel coronavirus (2019-nCoV) outbreak. Journal of Travel Medicine 27(2): 1-4. https://doi.org/10.1093/jtm/taaa020.

Zhang, C.H. \& Schwartz, G.G. 2020. Spatial disparities in coronavirus incidence and mortality in the United States: An ecological analysis as of May 2020. Journal of Rural Health 36(3): 433-445.

R. Azizah*, Santi Martini, Lilis Sulistyorini, Mahmudah, Aditya Sukma Pawitra, Stefanny Surya Nagari, Cendana Fitrahanjani, Fairuz Haniyah Ramadhani \& Mohd. Talib Latif

Faculty of Public Health

Universitas Airlangga

Surabaya

Indonesia

Didik Budijanto

The Ministry of Health of the Republic of Indonesia

Jakarta Selatan

12950 Jakarta

Indonesia

Mohd. Talib Latif

Faculty of Science and Technology

Universiti Kebangsaan Malaysia

43600 UKM Bangi, Selangor Darul Ehsan

Malaysia

*Corresponding author; email: azizah@fkm.unair.ac.id

Received: 5 November 2020

Accepted: 17 December 2020 